\title{
Presence of substance $P$ and neurokinin 1 receptors in human sputum macrophages and U-937 cells
}

\author{
P.R. Germonpre*, G.R. Bullock**, B.N. Lambrecht*, V. Van De Velde*, W.H.M.L. Luyten ${ }^{+}$, \\ G.F. Joos*, R.A. Pauwels*
}

Presence of substance $P$ and neurokinin 1 receptors in human sputum macrophages and $U$ 937 cells. P.R. Germonpre, G.R. Bullock, B.N. Lambrecht, V. Van De Velde, W.H.M.L. Luyten, G.F. Joos, R.A. Pauwels. (C)ERS Journals Ltd 1999.

ABSTRACT: Tachykinins such as substance P (SP) may be involved in the pathogenesis of inflammatory airway diseases such as asthma. This study investigated the presence of SP and its receptor in the differentiated macrophage-like $\mathrm{U}-937$ cell line and in macrophages from sputum induced in healthy subjects $(n=8)$.

In situ hybridization with digoxigenin-labelled sense and antisense complementary ribonucleic acid (cRNA) probes was used to determine the expression of SP and its receptor (neurokinin $(\mathrm{NK})_{1}$ receptor). SP-immunoreactive material was detected using a rabbit anti-SP antiserum and the alkaline phosphatase anti-alkaline phosphatase technique.

$\beta$-preprotachykinin (PPT)-I messenger ribonucleic acid (mRNA) encoding SP, was detected using in situ hybridization in differentiated U-937 cells as well as in CD45+ human leukocyte antigen (HLA) DR+ sputum macrophages. The expression of the $\beta$ PPT-I mRNA was increased in lipopolysaccharide (LPS)-stimulated U-937 cells. SPimmunoreactive material was found in differentiated U-937 cells and in CD68+ sputum macrophages. $\mathrm{NK}_{1}$ receptor $\mathrm{mRNA}$ was detected in differentiated $\mathrm{U}-937$ cells and sputum macrophages. Incubation of $\mathbf{U}-937$ cells with SP considerably increased the expression of $\mathrm{NK}_{1}$ receptor mRNA.

This study demonstrates that human monocytes/macrophages express substance $P$ and that this expression is upregulated by lipopolysacharide. Human monocytes/ macrophages also express neurokinin ${ }_{1}$ receptor messenger ribonucleic acid, suggesting an autocrine effect of substance $P$ on these cells.

Eur Respir J 1999; 14: 776-782.

The mammalian tachykinin substance P (SP) has been implicated in the pathogenesis of allergic asthma [1]. It can cause many of the typical changes observed in asthmatic airways: bronchoconstriction, increased mucus secretion, facilitation of cholinergic neurotransmission, vasodilatation and plasma leakage [2]. SP also has many immunomodulatory effects on mast cells, B- and T-lymphocytes, neutrophils, macrophages and eosinophils [3].

$\mathrm{SP}$ can be translated from three distinct messenger ribonucleic acids (mRNAs) $(\alpha, \beta$ and $\gamma$ ), which result from alternate splicing of the preprotachykinin-I (PPT-I) gene transcript. The PPT-I gene encodes SP, neurokinin (NK)A, neuropeptide $\mathrm{K}$ and neuropeptide- $\gamma$. The $\beta$-PPT-I mRNA contains all seven exons of the PPT-I gene, whereas the $\alpha-$ PPT-I and $\gamma$-PPT-I mRNAs lack the sixth and fourth exon, respectively [4]. Based on the rank order of potency of the endogenous tachykinins, three receptors are traditionally recognized and have been cloned: SP preferentially binds to the $\mathrm{NK}_{1}$ receptor, NKA to the $\mathrm{NK}_{2}$ receptor and $\mathrm{NKB}$ to the $\mathrm{NK}_{3}$ receptor [5]. Recently a fourth tachykinin receptor has been cloned. The detailed pharmacology of the $\mathrm{NK}_{4}$ receptor remains to be determined [6].

Significant amounts of SP are found in central and peripheral airway tissues [7], as well as in bronchoalveolar lavage (BAL) fluid [8] and sputum [9]. Increased am-
*Dept of Respiratory Diseases, University of Ghent, Belgium, **Dept of Pathology, University of Ghent, Belgium, ${ }^{+}$Dept of Experimental Molecular Biology, Janssen Research Foundation, Beerse, Belgium.

Correspondence: P.R. Germonpre, Dept of Respiratory Diseases, University Hospital Ghent, De Pintelaan 185, B-9000 Ghent, Belgium, Fax: 3292402341

Keywords: Immunocytochemistry, in situ hybridization, neurokinin-1 receptor, sputum macrophages, substance $\mathrm{P}, \mathrm{U}-937$ cell line

Received: September 31998

Accepted after revision June 291999

P.R.Germonpré and B.N.Lambrecht were recipients of a fellowship from the Fund for Scientific Research Flanders (FWOVlannderen). V. Van De Velde was a recipient of a fellowship from Boehringer Ingelheim, Belgium. This work was supported by a grant from the Fund for Scientific Research Flanders (Levenslijn 1994 project No. 37.0078.94) and the Janssen Research Foundation, Beerse, Belgium. ounts are also found in BAL fluid and sputum of asthmatics. The levels in BAL fluid increased after intrasegmental allergen challenge in atopics $[8,9]$. OLLERENSHAW et al. [10] described an increased number and length of SP-immunoreactive nerve fibres in the airways of asthmatics compared with nonasthmatics. Other authors, however, were unable to find any SP-containing nerves in bronchial biopsies of both asthmatics and nonasthmatics [11], while in post mortem specimens, the human airways were only sparsely innervated with SP-containing nerves $[12,13]$.

Thus, there appears to be a discrepancy between the scarce innervation of the lower airways with SP-containing nerve fibres and the amounts of SP found in airway wall extracts and airway fluids. Although it has been described mainly as a peptide of neuronal origin, studies in rodents have demonstrated its production by inflammatory cells, such as macrophages and eosinophils [14-16]. Recently, Ho et al. [17] reported the expression of SP by human peripheral blood monocytes and monocyte-derived macrophages.

This study examined the expression of SP and its receptor by macrophages derived from hypertonic saline-induced sputum of healthy, nonatopic volunteers and by the human monocytic cell line U-937, using in situ hybridization 
(ISH) and immunocytochemical techniques. The human monocytic U-937 cell line [18] was used as a model to study the expression of SP and its receptor by human macrophages. A combination of all-trans retinoic acid (RA) and 1,25-diOH-vitamin D3 (VD3) has been shown to bring the U-937 cells to a high stage of myeloid differentiation with macrophage-like properties [19].

\section{Methods}

\section{Subjects}

Eight healthy nonsmoking volunteers participated in this study. The exclusion criteria were a history of atopy, asthma, chronic obstructive pulmonary disease or respiratory infection in the 6 weeks preceding the study, as well as the use of corticosteroids, antihistamines or nonsteroidal antiinflammatory drugs in the 3 weeks preceding the study. The protocol was approved by the Ethics Committee of the University Hospital Ghent, and all participants gave their informed consent.

\section{Sputum induction and processing}

Sputum was induced and processed as described previously [20]. Briefly, sputum was induced by inhalation of increasing concentrations of hypertonic saline $(3,4$ and $5 \%$, which was nebulized with an ultrasonic nebulizer (Ultra-Neb $^{\mathrm{TM}}$ 2000; DeVilbiss Health Care Inc., Somerset, PA, USA). Sputum plugs were identified by visual inspection and the mucolytic agent dithiothreitol (Sputalysin, Calbiochem Corp., San Diego, CA, USA) was added to these plugs. The cell suspension was filtered through a $50 \mu \mathrm{m}$ gauze, centrifuged and resuspended in $0.01 \mathrm{M}$ phosphate buffered saline (PBS) pH 7.2 containing 2\% human serum albumin. Viability was determined by trypan blue exclusion (Sigma, St. Louis, MO, USA) and was always $>93 \%$.

Cytospin preparations were made on 3-aminopropyltriethoxy-silane coated slides by adding $5-6 \times 10^{4}$ cells into Shandon II cytocentrifuge cups (Shandon Southern Instruments, Sewickly, PA, USA) and centrifuging for $5 \mathrm{~min}$ at $400 \times g$. The slides were air dried and stored at $-70^{\circ} \mathrm{C}$ until processing.

\section{Cell sorting}

For flow cytometric cell sorting, dithiothreitol-treated sputum cells were washed twice in staining buffer $(2 \%$ bovine serum albumin (BSA), $0.02 \%$ sodium azide in PBS) prior to labelling with antibodies (Becton Dickinson, Aalst, Belgium). Cells were incubated with fluorescein isothiocyanate (FITC)-conjugated antibody directed against CD45 and with phycoerythrin (PE)-conjugated antibody against major histocompatibility complex (MHC) class II (human leukocyte antigen (HLA)-DR) for $30 \mathrm{~min}$ on ice. Large cells were gated based on forward angle and sideward scatter and sorting was performed on a population of cells that were HLA-DR ${ }^{\text {hi }}$ and CD45 $5^{\text {hi }}$ using a fluorescence activated cell sorting (FACS)-Vantage cell sorter equipped with a standard $488 \mathrm{~nm}$ argon laser and
CellQuest software (Becton Dickinson). The purity of the end-product was checked by re-analysis of the sorted fraction using flow cytometry and was found to be $>98 \%$. Cytospin preparations were made from $5 \times 10^{4}$ positively sorted cells.

\section{Cell culture}

U-937 cells were obtained from the American Type Culture Collection (ATCC; Rockville, MD, USA) and cultured as previously described [19]. The cells $\left(2 \times 10^{5}\right.$ cells $\cdot \mathrm{mL}^{-1}$ ) were differentiated with $100 \mathrm{nM} \mathrm{RA}$ and 100 nM VD3 (both from Sigma) for $96 \mathrm{~h}$. In a number of experiments, the cells were stimulated with lipopolysaccharide (LPS; $\left.25 \mu \mathrm{g} \cdot \mathrm{mL}^{-1}\right)$ or SP $(100 \mu \mathrm{M})$ (both from Sigma) during the last $16 \mathrm{~h}$ of differentiation. Cell viability was determined by trypan blue exclusion and cytospins were prepared as described above.

\section{Immunolabelling}

The rabbit anti-SP antiserum used for immunocytochemistry has been described previously [21]. The specificity of the antiserum for SP was validated by radioimmunoassay: cross-reactivity with NKA and NKB was $0.01 \%$ and $0.04 \%$ respectively. Immunocytochemical staining was effectively blocked with $0.1 \mu \mathrm{g} \mathrm{SP} \cdot \mathrm{mL}^{-1}$ diluted antiserum.

Immunocytochemistry was performed as previously described [22]. The cells were thawed and fixed with $1 \%$ paraformaldehyde in PBS for $20 \mathrm{~min}$. After fixation the cells were rinsed with $0.05 \mathrm{M}$ Tris-buffered saline, $\mathrm{pH}$ 7.35 (TBS), and incubated overnight with the primary antibody diluted in TBS $(1 / 500-1 / 1,000)$. The primary antibody was detected with the alkaline phosphatase antialkaline phosphatase (APAAP) technique using secondary rat anti-rabbit antibody and rat APAAP complex (both from Dako A/S, Glostrup, Denmark) diluted 1/25 in TBS. The alkaline phosphatase was developed with New Fuchsin (Dako) as chromogen, yielding a red precipitate. Levamisole $(1 \mathrm{mM})$ was added to block any endogenous alkaline phosphatase activity. Mayer's hematoxylin was used as a counterstain. The specificity of the immunostaining was confirmed either by using nonimmune rabbit serum or TBS instead of primary antiserum.

\section{Immunofluorescent double labelling}

The cells were fixed as described above. To reduce background signal, the cells were incubated with $10 \%$ nonimmune goat serum (Sigma) in TBS containing 1\% BSA prior to the application of the primary antibodies. All antibody dilutions and wash steps were made in TBS containing $1 \%$ BSA. The cells were incubated overnight at ambient temperature with the rabbit anti-SP antibody (1/ 500). The following day, the goat anti-rabbit antibody labelled with Oregon Green (1/1000) (Molecular Probes, Leiden, the Netherlands) was applied for $1 \mathrm{~h}$ in the dark. This was then followed by the mouse monoclonal antiCD68 antibody (1/200) (Dako) and the goat anti-mouse 
antibody labelled with tetramethylrhodamine isothiocyanate (TRITC) (1/100) (Sigma) which were also applied in the dark for $1 \mathrm{~h}$ each. Nonimmune rabbit serum and monoclonal mouse immunoglobulin (Ig)G1 raised against a non-human antigen (X 931; Dako) were used as negative controls.

\section{Probe preparation}

A pGEM3 vector containing a 416 base pair (bp) fragment of the human $\beta$-PPT-I complementary deoxyribonucleic acid (cDNA) (starting from the major transcription initiation site) was kindly provided by P. Voorn (Vrije Universiteit Amsterdam, the Netherlands). This fragment includes introns 1-5 and part of intron 6 of the PPT-I gene. A pUC19 vector containing the complete coding sequence of the human $\mathrm{NK}_{1}$ receptor was kindly provided by $\mathrm{M}$. De Backer (Janssen Research Foundation, Beerse, Belgium). A 537 bp 3'-fragment was subcloned into the pBluescript KS- II vector (Stratagene, San Diego, CA, USA). Antisense and sense complementary ribonucleic acid (cRNA) probes were prepared by linearizing the plasmids (with HindIII, EcoRI or NotI) and transcribing with RNA polymerase T3, T7 or SP6 (MEGAscript ${ }^{\text {TM }}$ kits; Ambion Inc., Austin, TX, USA). The probes were labelled by the incorporation of digoxigenin (DIG)-labelled uridine triphosphate (UTP) (Boehringer Mannheim, Mannheim, Germany). Unincorporated nucleotides were removed using G-25 Sephadex columns (Boehringer Mannheim).

\section{In situ hybridization}

Slides were processed in parallel to avoid variations in staining intensities attributable to processing. The cells were thawed out and fixed for 10 min with freshly prepared 4\% paraformaldehyde in PBS. Nonspecific probe binding was blocked by acetylation with $0.25 \%$ acetic anhydride in $0.1 \mathrm{M}$ triethanolamine, $\mathrm{pH}$ 8.0. Prehybridization was performed for $4 \mathrm{~h}$ at $72^{\circ} \mathrm{C}$ with $70 \mu \mathrm{L}$ hybridization buffer $(50 \%$ deionized formamide containing $5 \times$ standard saline citrate (SSC), $0.1 \%$ Ficoll $400,0.1 \%$ polyvinylpyrrolidone, $0.1 \% \mathrm{BSA}, 500 \mu \mathrm{g} \cdot \mathrm{mL}^{-1}$ yeast transfer (t)RNA and $500 \mu \mathrm{g} \cdot \mathrm{mL}^{-1}$ heat-denatured salmon sperm DNA). Subsequently, $70 \mu \mathrm{L}$ hybridization buffer containing $1 \mathrm{ng} \cdot \mu \mathrm{L}^{-1}$ DIG-labelled riboprobe was applied and the cells were incubated overnight at $72{ }^{\circ} \mathrm{C}$ in a humidified chamber. The cells were washed with $2 \times \mathrm{SSC}$, followed by a second wash in $50 \%$ formamide in $5 \times$ SSC at $55^{\circ} \mathrm{C}$. Hybridized probe was detected using a DIGdetection kit (Boehringer Mannheim) according to the manufacturer's instructions. The alkaline phosphatase was developed overnight with nitro blue tetrazolium and 5bromo-4-chloro-3-indolyl phosphate, in the presence of 1 $\mathrm{mM}$ levamisole, yielding a blue-black precipitate.

\section{Analysis of results and quantification of staining}

Slides were examined using a Zeiss Axiophot microscope (Zeiss, Oberkochen, Germany). The staining of the ISH experiments was assessed semi - quantitatively as follows, -: no staining; +: weak staining; ++: moderate staining; +++: strong staining. At least 200 cells per cytospin were rated. All ratings were performed in a blinded fashion by two investigators (P.R. Germonpré and V. Van De Velde). The interobserver correlation was $\geq 90 \%$.

\section{Results}

\section{In situ hybridization with $\beta$-preprotachykinin-I probes}

ISH with the DIG-labeled antisense cRNA probe for $\beta$ PPT-I demonstrated the presence of messenger (m)RNA for SP in the cytoplasm of RA- and VD3-differentiated U937 cells (fig. 1b). Overnight incubation of the differentiated U-937 cells with LPS $\left(25 \mu \mathrm{g} \cdot \mathrm{mL}^{-1}\right)$ caused an increase of the hybridization signal for $\beta$-PPT-I (fig. 1c and table 1). This increased hybridization signal was mainly localized in the nuclei of the U-937 cells. This suggests an increase in the transcription of the PPT-I gene.

The concentration of SP in the cell pellet and in the culture supernatant of the differentiated U-937 cells was
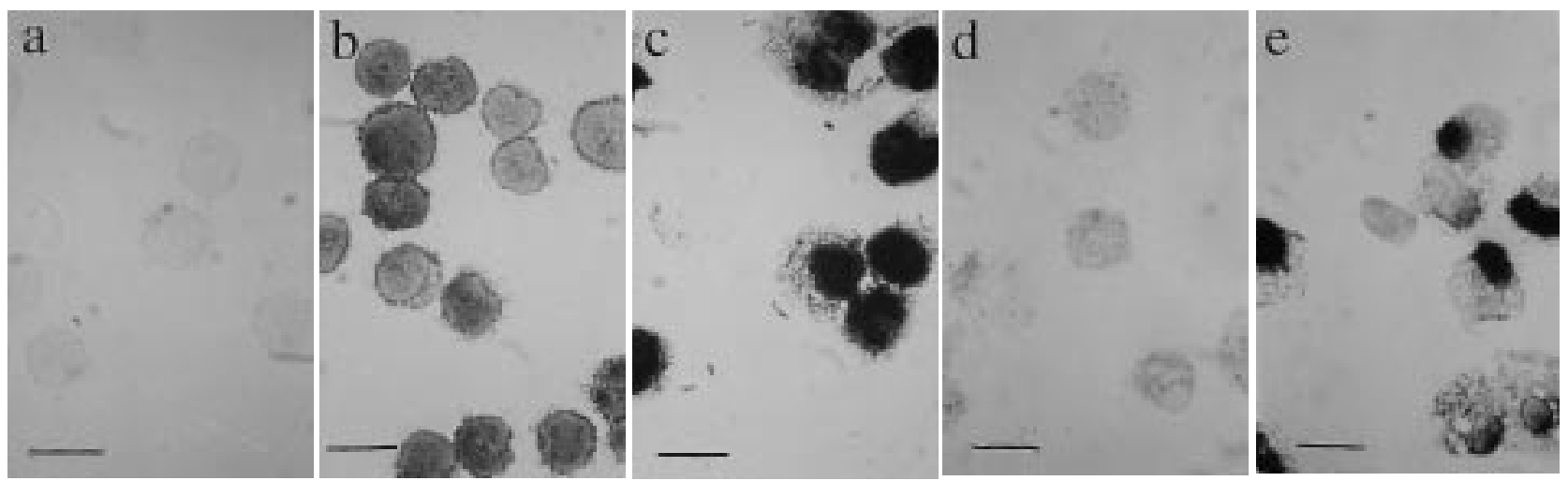

Fig. 1. - Substance-P in situ hybridization (ISH) of U-937 and sputum cells from normal healthy subjects. ISH with the digoxigenin-labelled sense $\beta$ preprotachykinin (PPT)-I complementary ribonucleic acid (cRNA) probe produced no staining (a), while ISH with the antisense probe produced an intense hybridization signal (blue precipitate) in all trans-retinoic acid and 1,25 diOH-vitamin D3-differentiated U-937 cells (b). Overnight incubation with lipopolysaccharide (LPS) $\left(25 \mu \mathrm{g} \cdot \mathrm{mL}^{-1}\right)$ significantly increased the hybridization signal (c). In FACS-sorted human leukocyte antigen DR+ CD45+ sputum macrophages, ISH with the sense $\beta$-PPT-I cRNA probe also caused no background staining (d), while the antisense probe produced a signal similar to that observed in LPS-stimulated U-937 cells (e). (Internal scale bars=16 $\mu \mathrm{m}$ ). 
Table 1. - Scoring of the in situ hybridization signal from the human $\beta$-preprotachykinin-I antisense ribonucleic acid probe in U-937 cells differentiated with all-trans retinoic acid and 1,25-diOH-vitamin D3 (100 nM each for $96 \mathrm{~h}$ )

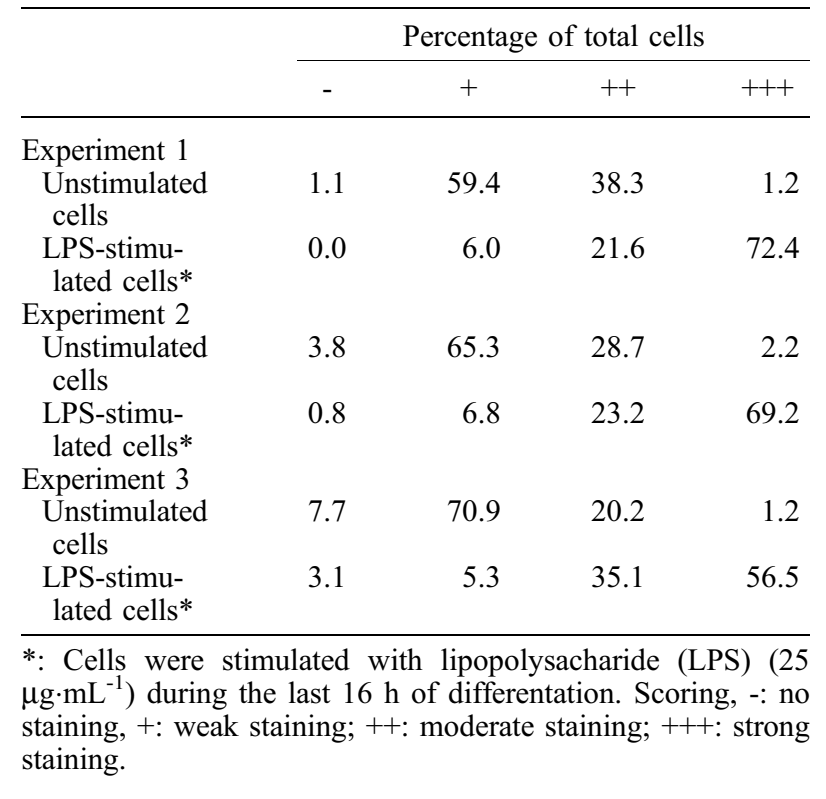

determined using an enzyme-linked immunosorbent assay (ELISA)-technique $\left(136 \mathrm{pg} \cdot 10^{6}\right.$ cells $^{-1}$ and $44 \mathrm{pg} \cdot 10^{6}$ cells $^{-1}$ respectively). Incubation of the U-937 cells with LPS $\left(25 \mu \mathrm{g} \cdot \mathrm{mL}^{-1}\right)$ had no effect on the concentration in the supernatant, but increased the SP-content in the cell pellets to $356 \pm 155 \%$ of baseline SP-content $(n=3)$. These observations support the hypothesis that stimulation of the U-937 cells with endotoxin increases the expression and intracellullar content of SP, without affecting its secretion.

The possible expression of the $\beta$-PPI-I mRNA in FACSsorted sputum cells was then studied. Using the $\beta$-PPT-I antisense probes, an intense hybridization signal in the CD45+/HLA DR+ cells was found, which are purified monocytes and macrophages (fig. 1e). The distribution of the hybridization signal in the CD45+/HLA DR+ cells was similar to that found in LPS-stimulated U-937 cells: strong nuclear signal with some cytoplasmatic staining. In the CD45 +/HLA DR- cell fraction, consisting mainly of neutrophils and lymphocytes, no significant hybridization signal was found (data not shown). These results show that sputum monocytes and macrophages from normal subjects express mRNA for SP.

The DIG-labelled sense $\beta$-PPT-I cRNA probe produced no background staining demonstrating the specificity of the hybridization of the antisense probe (figs. 1a and d).

\section{Immunocytochemical detection of the substance P pep- tide}

Using a highly selective rabbit anti-SP antibody [21], SP-immunoreactive material was detected in differentiated U-937 cells (data not shown) and in human sputum cells (figs. 2a and b). These sputum cells had the morphological appearance of macrophages. The percentage of macrophages staining for SP-immunoreactivity ranged 30-60\%. Immunofluorescent double labelling with a monoclonal anti-CD68 antibody following treatment with the polyclonal anti-SP antibody confirmed that all SPimmunoreactive cells belonged to the monocyte/macrophage lineage (figs. 2c and d).

In situ hybridization with human neurokinin 1 receptor probes

The DIG-labelled antisense $\mathrm{NK}_{1}$ receptor cRNA probe detected $\mathrm{NK}_{1}$ receptor mRNA in differentiated U-937 cells (figs. $3 \mathrm{a}$ and $\mathrm{b}$ ). Overnight incubation of the differentiated U-937 cells with exogenous SP $(100 \mu \mathrm{M})$ increased the staining for $\mathrm{NK}_{1}$ receptor mRNA (fig. $3 \mathrm{c}$ and table 2 ). This suggests that SP can upregulate the expression of its own receptor. The hybridization signal for $\mathrm{NK}_{1}$ receptor mRNA was also found in sputum cells with the appearance of macrophages.

\section{Discussion}

This study has shown that the human monocytic U-937 cell line and sputum macrophages from normal subjects
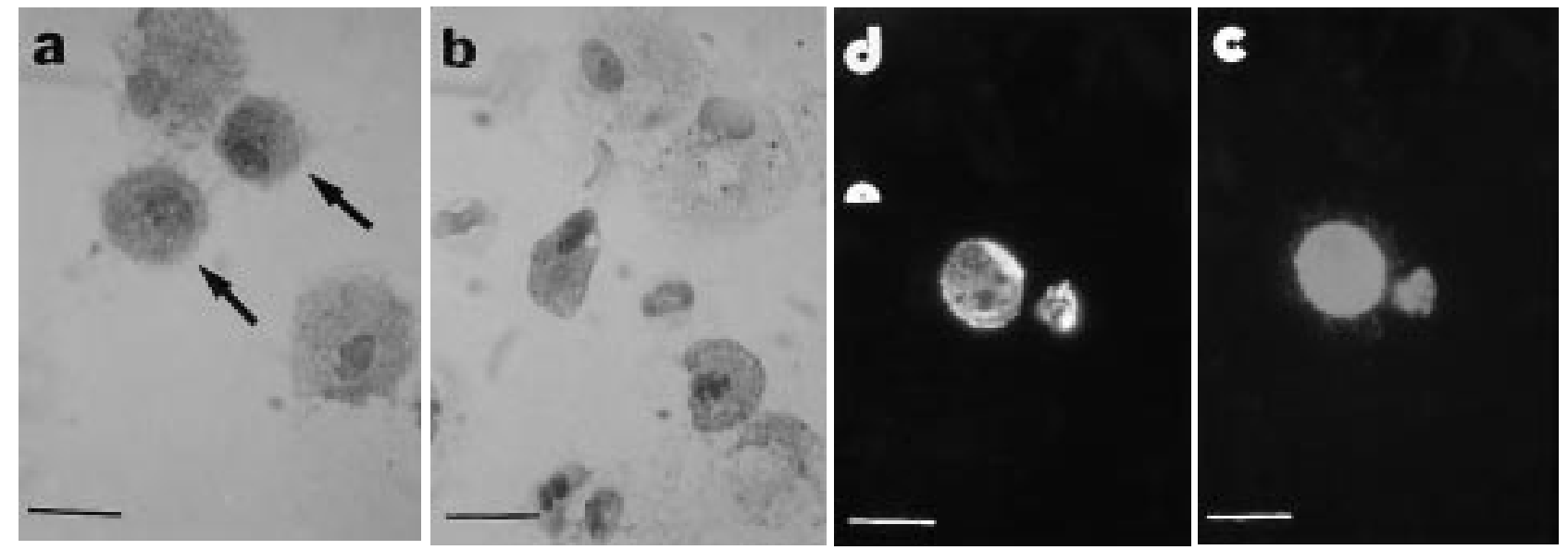

Fig. 2. - a) Immunostaining with the rabbit anti-substance P (SP) antibody showed SP-immunoreactivity (red precipitate) in sputum cells with the morphology of macrophages (arrows); b) labelling with nonimmune rabbit serum produced no staining; c) Immunofluorescent double labelling of sputum cells with anti-CD68 (detected with TRITC) and d) rabbit anti-SP antibody (detected with Oregon Green). (Internal scale bars=16 $\mu$ m). 

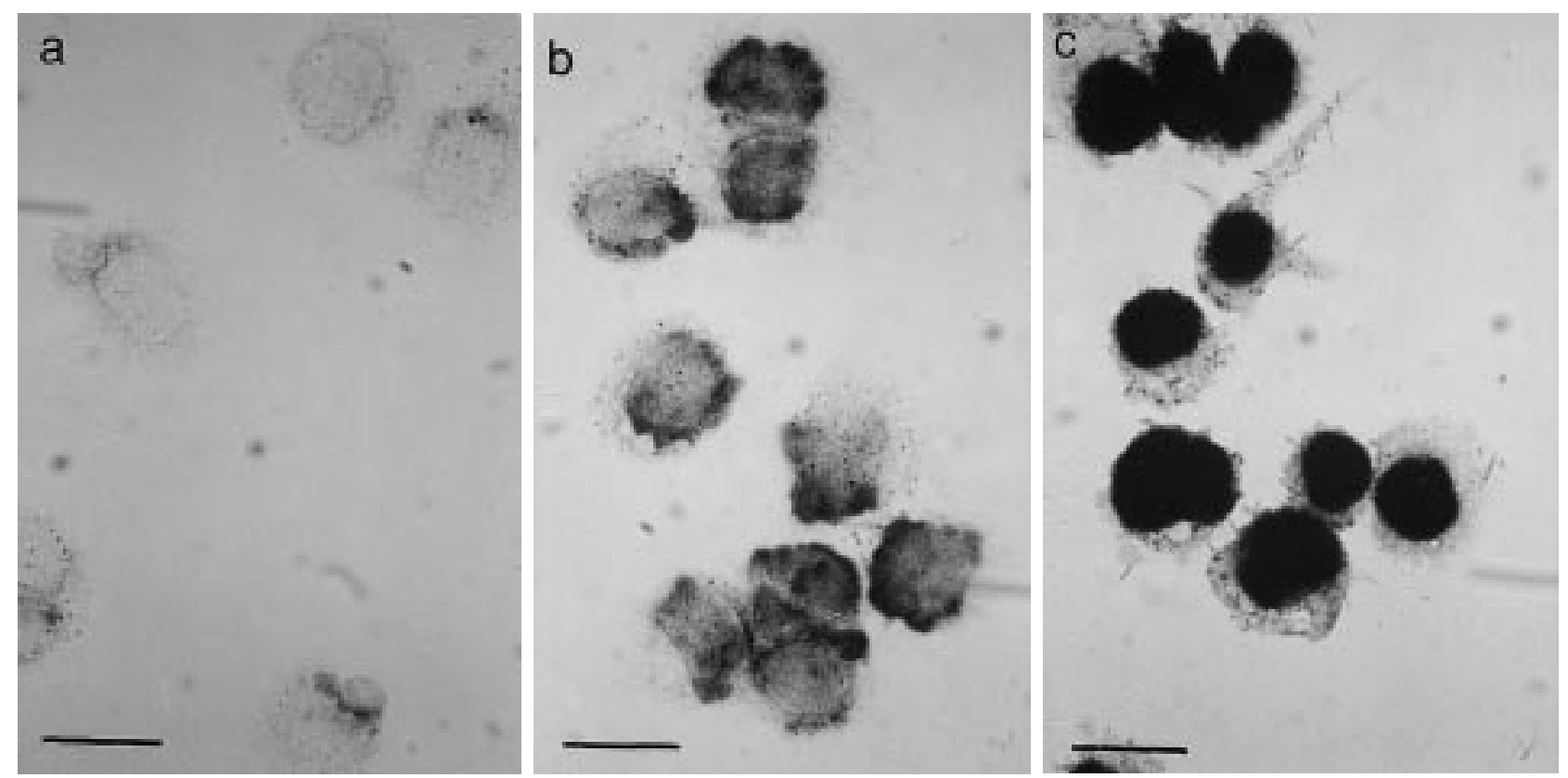

Fig. 3. - In situ hybridization with the digoxigenin-labelled sense $\beta$-preprotachykinin-I human neurokinin 1 receptor probe produced no staining (a), while hybridization with the antisense probe produced an intense hybridization signal (blue precipitate) in all trans-retinoic acid and 1, 25-diOH-vitamin D3-differentiated U-937 cells (b). Overnight incubation with substance P (100 $\mu \mathrm{M})$ significantly increased the hybridization signal (c).(Internal scale bars $=16 \mu \mathrm{m})$

express both mRNA for SP and SP-immunoreactive material. The differentiated U-937 cells and sputum macrophages also express mRNA for the $\mathrm{NK}_{1}$ receptor. These findings demonstrate that human macrophages are able to produce SP and its receptor.

By a combination of RA and VD3, the U-937 cells were brought to a high stage of myeloid differentiation with major characteristics of monocytes/macrophages [19]. These U-397 cells with macrophage-like properties and human

Table 2. - Scoring of the in situ hybridization signal from the human neurokinin-1 receptor antisense complementary ribonucleic acid probe in U-937 cells differentiated with all-trans retinoic acid and 1,25-diOH vitamin D3 (100 $\mathrm{nM}$ each for $96 \mathrm{~h}$ )

\begin{tabular}{lcccc}
\hline & \multicolumn{4}{c}{ Percentage of total cells } \\
\cline { 2 - 5 } & - & + & ++ & +++ \\
\hline $\begin{array}{c}\text { Experiment 1 } \\
\text { Unstimulated } \\
\text { cells }\end{array}$ & 0.7 & 72.2 & 20.5 & 6.6 \\
$\begin{array}{c}\text { SP-stimu- } \\
\text { lated cells* }\end{array}$ & 0.0 & 19.4 & 15.3 & 65.3 \\
$\begin{array}{c}\text { Experiment 2 } \\
\text { Unstimulated } \\
\text { cells }\end{array}$ & 5.7 & 67.2 & 17.0 & 10.1 \\
$\begin{array}{c}\text { SP-stimu- } \\
\text { lated cells* }\end{array}$ & 1.3 & 23.6 & 22.7 & 52.4 \\
$\begin{array}{c}\text { Experiment 3 } \\
\text { Unstimulated } \\
\text { cells }\end{array}$ & 0.1 & 66.0 & 31.1 & 2.8 \\
$\begin{array}{c}\text { SP-stimu- } \\
\text { lated cells* }\end{array}$ & 4.5 & 13.5 & 19.4 & 62.6 \\
\hline
\end{tabular}

*: Cells were stimulated with substance P (SP) $(100 \mu \mathrm{M})$ during the last $16 \mathrm{~h}$ of differentiation. Scoring, -: no staining; +: weak staining; ++: moderate staining; +++: strong staining.
HLA DR+ CD45+ sputum macrophages expressed mRNA for SP under basal conditions. Upon stimulation with bacterial endotoxin, a marked increase of the $\beta$-PPI-I mRNA and SP content in the differentiated U-937 cell line was observed. Using a highly specific anti-SP antiserum, SP-immunoreactivity in differentiated U-937 cells as well as in human CD68+ sputum macrophages was found. Thus, in addition to sensory nerve fibres, human macrophages are a source of SP in the airways.

These results are consistent with the observations of KILLINGSWORTH et al. [16], who found that rat alveolar macrophages express PPT-I rnRNA which is upregulated by LPS. In a rat model of chronic bronchitis, a 3-fold increase of the SP-content was found in the trachea, but there was no difference in the PPT-I mRNA in the cell bodies of the $\mathrm{C}$-fibres innervating the airways [23]. Similarly, elevated concentrations of SP are found in sputum and BAL fluids from asthmatics [8,9], while significantly less SP-immunoreactivity was found in tracheal tissue from asthmatic than from nonasthmatic patients [7]. With the exception of one study [10], few if any SP-containing nerves are found in human airways of both asthmatic and normal subjects [11-13]. This discrepancy between the sparse innervation with SP-immunoreactive nerves and the elevated SP content in sputum and BAL fluids, may be due to an increased release of SP from the sensory nerves. However, the present findings together with the data from animal studies [16, 23], suggest that airway macrophages may be the source of the increased amounts of SP found in inflammatory airway diseases.

Using in situ hybridization with a human $\mathrm{NK}_{1}$ receptor cRNA probe, the results are also able to demonstrate the presence of mRNAs encoding for the $\mathrm{NK}_{1}$ receptor in differentiated U-937 cells and in human sputum macrophages. These findings in mature tissue macrophages confirm and expand the observations of Ho et al. [17] that 
human peripheral blood monocyte-derived macrophages express both $\beta$-PPT-I and $\mathrm{NK}_{1}$ receptor mRNA. Previously, SP has been shown to enhance phagocytosis, evoke superoxide anion production and cytokine release by macrophages [24-27]. SP may therefore have an important autocrine effect on human macrophages.

Incubation with exogenous SP increased the human $\mathrm{NK}_{1}$ receptor mRNA in differentiated U-937 cells. This indicates that the expression of the $\mathrm{NK}_{1}$ receptor is upregulated following its activation by $\mathrm{SP}$. The $\mathrm{NK}_{1}$ receptor gene expression is increased in lungs from patients with asthma and chronic obstructive pulmonary disease [28, 29]. Supporting evidence from recent animal studies using $\mathrm{NK}_{1}$ receptor antagonists and $\mathrm{NK}_{1}$ receptor gene knockout mice, indicate that the $\mathrm{NK}_{1}$ receptor may be involved in the pathogenesis of airway inflammation [ 30 , 31]. Increased expression of $\mathrm{NK}_{1}$ receptor mRNA by alveolar macrophages was observed in a murine model of antigen-induced airway inflammation, this increase of the $\mathrm{NK}_{1}$ receptor mRNA (days 2-6) following on an increase of the SP-content of the BAL fluid (days 1-3) [30].

In conclusion, this results demonstrate that differentiated human monocytic U-937 cells and human sputum macrophages produce substance $\mathrm{P}$. The expression of substance $\mathrm{P}$ by monocytes/macrophages is upregulated by endotoxin, indicating that airway macrophages might be a source of the increased amounts of substance P found in inflammatory airway diseases. Human monocytes/macrophages also express messenger ribonucleic acid for the neurokinin 1 receptor, suggesting an autocrine effect of substance $\mathrm{P}$ on macrophages.

\begin{abstract}
Acknowledgements. The authors thank P. Petrusz (Chapel Hill, NC, USA) for the gift of the anti-SP antiserum, B. Hengerer (Novartis AG, Basel) for help with setting up the ISH-technique, P. Geppetti (University of Ferrara, Italy) for the ELISA-measurements of SP, P. Van Gompel and I. DeBorle for their expert technical assistance.
\end{abstract}

\section{References}

1. Barnes PJ. Asthma as an axon reflex. Lancet 1986; i: 242-244.

2. Joos GF, Germonpré PR, Kips JC, Peleman RA, Pauwels RA. Sensory neuropeptides and the human lower airways: present state and future directions. Eur Respir J 1994; 7 : 1161-1171.

3. Maggi CA. The effects of tachykinins on inflammatory and immune cells. Regul Pept 1997; 70: 75-90.

4. Harmar AJ, Armstrong A, Pascal JC, et al. cDNA sequence of human $\beta$-preprotachykinin, the common precursor to substance P and neurokinin A. FEBS Lett 1986; 208: 67-72.

5. Nakanishi S. Mammalian tachykinin receptors. Annu Rev Neurosci 1991; 14: 123-136.

6. Donaldson LF, Haskell CA, Hanley MR. Functional characterization by heterologous expression of a novel cloned tachykinin peptide receptor. Biochem $J$ 1996; 320: 1-5.

7. Lilly CM, Bai TR, Shore SA, Hall AK, Drazen JM. Neuropeptide content of lungs from asthmatic and non- asthmatic patients. Am J Respir Crit Care Med 1995; 151 : 548-553.

8. Nieber K, Baumgarten CR, Rathsack R, Furkert J, Oehme P, Kunkel G. Substance P and $\beta$-endorphine-like immunoreactivity in lavage fluids of subjects with and without allergic asthma. J Allergy Clin Immunol 1992; 90: 646652.

9. Tomaki M, Ichinose M, Miura M, et al. Elevated substance $\mathrm{P}$ content in induced sputum from patients with asthma and patients with chronic bronchitis. Am J Respir Crit Care Med 1995; 151: 613-617.

10. Ollerenshaw SL, Jarvis D, Sullivan CE, Woolcock AJ. Substance P immunoreactive nerves in airways from asthmatics and nonasthmatics. Eur Respir J 1991; 4: 673682.

11. Howarth PH, Djukanovic R, Wilson JW, Holgate ST, Springall DR, Polak JM. Mucosal nerves in endobronchial biopsies in asthma and non-asthma. Int Arch Allergy Immunol 1991; 94: 330-333.

12. Luts A, Uddman R, Alm P, Basterra J, Sundler F. Peptidecontaining nerve fibers in human airways: distribution and coexistence pattern. Int Arch Allergy Immunol 1993; 101: 52-60.

13. Komatsu T, Yamamoto $M$, Shimokata $K$, Nagura $H$. Distribution of substance P-immunoreactive and calcitonin gene-related peptide in normal human lungs. Int Arch Allergy Immunol 1991; 95: 23-28.

14. Bost KL, Breeding SA, Pascual DW. Modulation of the mRNAs encoding the substance $\mathrm{P}$ and its receptor in rat macrophage by LPS. Reg Immunol 1992; 4: 105-112.

15. Weinstock JL, Blum A, Walder J, Walder R. Eosinophils from granulomas in murine Schistosomiasis Mansoni produce substance P. J Immunol 1988; 141: 961-966.

16. Killingsworth CR, Shore SA, Alessandrini F, Dey RD, Paulauskis JD. Rat alveolar macrophages express preprotachykinin gene-I mRNA-encoding tachykinins. Am J Physiol 1997; 273: L1073-L1081.

17. Ho W-Z, Lai J-P, Zhu X-H, Uvaydova M, Douglas SD. Human monocytes and macrophages express substance $\mathrm{P}$ and neurokinin-1 receptor. J Immunol 1997; 159: 56545660.

18. Sundström C, Nilsson K. Establishment and characterization of a human histiocytic lymphoma cell line (U937). Int J Cancer 1976; 17: 565-577.

19. Taimi M, Defacque H, Commes T, et al. Effect of retinoic acid and vitamin D on the expression of interleukin-1 $\beta$, tumour necrosis factor-alpha and interleukin-6 in the human monocytic cell line U937. Immunology 1993; 79: 229-235.

20. Pizzichini E, Pizzichini MMM, Efthimiades A, et al. Indices of airway inflammation in induced sputum: reproducibility and validity of cell and fluid phase measurements. Am J Respir Crit Care Med 1996; 154: 308-317.

21. Suarez-Roca H, Maixner W. Delta-opioid-receptor activation by [D-Pen2, D-Pen5]enkephalin and morphine inhibits substance $\mathrm{P}$ release from trigeminal nucleus slices. Eur J Pharmacol 1992; 229: 1-7.

22. Mueller R, Chanez P, Campbell AM, Bousquet J, Heusser C, Bullock GR. Different cytokine patterns in bronchial biopies in asthma and chronic bronchitis. Respiratory Medicine 1996; 90: 79-85.

23. Killingsworth C, Paulauskis JD, Shore SA. Substance P content and preprotachykinin gene-1 mRNA expression in a rat model of chronic bronchitis. Am J Respir Cell Mol Biol 1996; 14: 334-340.

24. Bar-Shavit Z, Goldman R, Stabinsky Y, et al. Enhancement of phagocytosis: a newly found activity of substance 
$\mathrm{P}$ residing in its $\mathrm{N}$-terminal tetrapeptide sequence. Biochem Biophys Res Comm 1980; 94: 1445-1451.

25. Murris-Espin M, Pinelli E, Pipy B, Leophonte P, Didier A. Substance $P$ and alveolar macrophages: effects on oxidative metabolism and eicosanoid production. Allergy 1995; 50: 334-339.

26. Kincy-Cain T, Bost KL. Substance P-induced IL-12 production by murine macrophages. J Immunol 1997; 158: 2334-2339.

27. Kimball ES, Persico FJ, Vaught JL. Substance P, neurokinin A, and neurokinin B induce generation of IL-1 like activity in P388D1 cells. J Immunol 1988; 141: 35643569.

28. Bai TR, Zhou D, Weir T, et al. Substance P (NK1)-and neurokinin A (NK2)-receptor gene expression in inflammatory airway disease. Am J Physiol 1995; 269: L309L317.

29. Adcock IM, Peters M, Gelder C, Shirasaki H, Brown CR, Barnes PJ. Increased tachykinin receptor gene expression in asthmatic lung and its modulation by steroids. $J$ Molec Endocrinol 1993; 11: 1-7.

30. Kaltreider HB, Ichikawa S, Byrd PK, et al. Upregulation of neuropeptides and neuropeptide receptors in a murine model of immune inflammation in lung parenchyma. $\mathrm{Am}$ J Respir Cell Mol Biol 1997; 16: 133-144.

31. Bozic CR, Lu B, Höpken UE, Gerard C, Gerard NP. Neurogenic amplification of immune complex inflammation. Science 1996; 273: 1722-1725. 